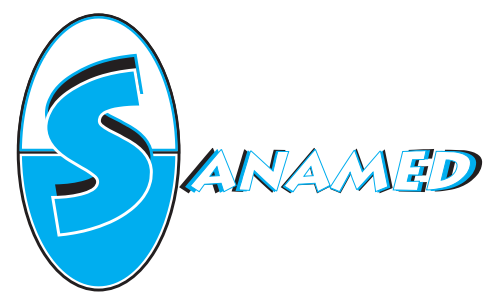

\title{
Riječ urednika
}

Poštovani,

treću svesku ovog broja za 2016-tu godinu, kao što znate jubilarnu, jer je deset godina kako časopis izlazi, obeležavaju dvije stvari. Prva stvar je potvrda uspješnosti rada na ovom časopisu i potvrda zrelosti ekipe koja ga je uređivala svih ovih deset godina. Vodili smo računa prvenstveno na kvalitet $i$ ozbiljnost. Veliki je značaj svih naših saradnika širom svijeta koji su nam svesrdno pomogli u tome. Pratili su naš rad i tamo gdje se to od njih očekivalo, otklanjali sve manjkavosti kako bi ,SANAMED“-u dali ozbiljniji i stručniji karakter.

Druga stvar je što pred sobom imamo jedan potpuno standardizovan i uspješno sazreo časopis koji u sledeće godine svog rada ulazi kao uspješno predstavljen naučnoj eliti stručnjaka medicinskih nauka koja se družila svih ovih deset godina i omogućila da ga mnogi širom svijeta upoznaju i useli se $u$ vitrine mnogih biblioteka.

Obe ove stvari su utabale siguran put za lakši budući rad koji će i dalje zahtijevati energiju, znanje $i$ istu efikasnost kako bi časopis, sada sa mjesta blizu vrha, stigao na vrh ili među prvima sa vrha.

Bez obzira na trud da se naš časopis popne još više na lestvici priznatih, neke od onih koji su odlučivali o njegovoj kategorizaciji je čudilo to otkud baš ovaj časopis iz jedne male oaze da se pojavi $i$ takmiči sa časopisima sa mnogo dužom tradicijom $i$ iz velikih univerzitetskih centara, i za koje je bilo logično da sa manje truda zauzmu mesto na tronu. Uputio bih i zamerku onima koji su čak bili hrabri da pitaju kako to da i Novi Pazar, odnosno lekarski esnaf ovog malog grada, ima tako jedan ozbiljan časopis. Ne bih se ovog puta bavio time, ali ih podsjećam da slijedeći put budu objektivniji i ne gledaju odakle je časopis, već šta sadrži i koji kvalitet nosi. Istakao bih takođe i to da baš ove godine je proslavljena jubilarna desetogodišnjica Državnog Univerziteta u Novom Pazaru, što je još jedan raz-

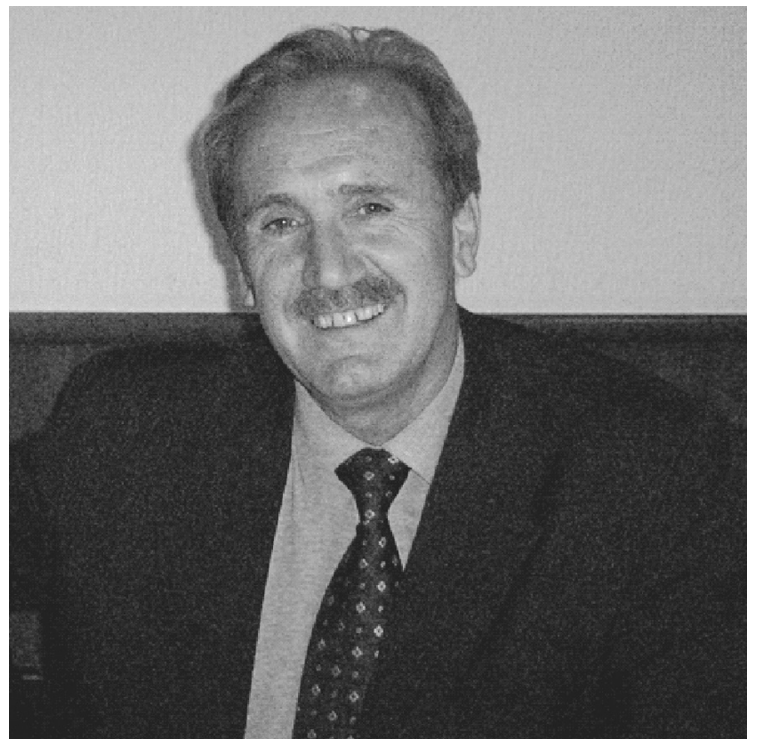

log da smo ponosni na tu činjenicu zajedničkog sazrijevanja i visokog uspjeha, bez namjere bilo kakvog uporedivanja.

Raditi sve ove godine zahtijevalo je trud i vrijeme, crpeći znanje ljudi od struke širom svijeta, ali bez novca to ne bi moglo baš da se uspješno ostvari. Na svu sreću svi oni koji su vezani za naš časopis su volonteri, a onaj dio koji je vezan za štampanje $i$ elektronsko oglašavanje i održavanje na sajtu ipak zahtijeva novac. Ponekad se javi i neki sponzor, ali vrlo često finasiranje ide iz kase uređivačkog tima. Zadnjih par godina se oko 65\% troškova samofinansira preko korisnika časopisa.

Ovim putem htio bih da pozdravim, prije svega najuži tim ljudi u uređivačkom tijelu i sve one širom svijeta koji su dio velikog tima i bez kojih ne bi mogli biti uspješni i da im čestitam Novu 2017 godinu. Želim im pre svega da su zdravi, živi i da im čitav radni $i$ životni vijek protekne u sreći i blagostanju. Srećni i zdravi bili i dočekali novi jubilej od dvadest godina rada.

Prim. dr Avdo Ćeranić Glavni i odgovorni urednik 